\title{
ZONASI FISIOMORFOHIDRO DI JAWA BARAT DENGAN MENGGUNAKAN APLIKASI SIG
}

\author{
Iwan Setiawan ${ }^{1}$, Dede Rohmat ${ }^{2}$ \\ 1Jurusan Pendidikan Geografi, FPIPS, UPI, iwan4671@gmail.com \\ 2Jurusan Pendidikan Geografi, FPIPS, UPI, rohmat_dede@yahoo.com
}

\begin{abstract}
Rainfall data has collected from rain station which is attached by certain institution like Meteorology Climatology and Geophysics Agency or another institution to fulfill the need of rainfall data at certain location, such as paunch otority, communication and transportasion agency etc. The problem: is the existing rain station distribution has covers rain parameters such as altitude, morphology, and rain distribution, with the result that every parameters represented for every parameters? Here by the objectives of this research is to mapping and analiyzing rain station distribution wich is related to those parameters. If those three map overlay then produce fisiomorphohydro zone. Overlay of three map with GIS Aplication is used to analysis. The result of this research shows that West Java have 90 zone of fisiomorphohydro. The composite map shows that West Java hasn't even rain station distribution. Based on overlay of fisiomorhohydro zonation map and rainfall station distributions of West Java, then we find out that there are many zonation which hasn't representative rain station.
\end{abstract}

Keywords: zonation, fisiomorfohydro, GIS Application, fisiography,topography, rainfal, isohyet, rain intensity, distribution, rain station

\section{PENDAHULUAN}

\section{Latar Belakang}

Data curah hujan sangat diperlukan manusia untuk melakukan berbagai perencanaan terkait dengan desain bangunan teknis seperti waduk, jembatan, saluran drainase, dan lain-lain. Selain itu, data curah hujan juga sangat diperlukan untuk perencanaan dalam bidang pertanian, kehutanan, transportasi dan lain-lain.

Besarnya kebutuhan akan data curah hujan tidak sebanding dengan upaya untuk menjamin ketersediaannya dan memanfaatkan data tersebut secara optimal. Desain bangunan teknis untuk saluran drainase misalnya seringkali dibuat dengan dimensi yang tidak sesuai dengan intensitas hujan yang terjadi, sehingga tidak efektif menampung dan mengalirkan air hujan. Karena itu, diperlukan upaya memetakan stasiun hujan dengan menggunakan parameterparameter yang dapat mempengaruhi hujan, sehingga penempatan stasiun hujan representative mewakili suatu unit area tertentu. Stasiun hujan pewakil ini diasumsikan berlaku untuk luasan area tertentu yang secara fisiografis, 
morfologis dan hidrologis memiliki kesamaan, sehingga curah hujan juga diasumsikan sama. Zonasi tersebut dinamakan sebagai zona fisiomorfohidro. Dengan cara demikian, dapat ditentukan stasiun hujan pewakil untuk keperluan analisis tertentu dan analisis sebaran stasiun hujan.

Untuk kepentingan tersebut, diperlukan suatu cara pemetaan yang dapat menumpangsusunkan peta-peta yang menjadi parameter dalam menentukan zona fisiomorfohidro. Peta-peta tersebut adalah peta topografi, peta fisiografi, dan peta isohyets. Aplikasi SIG dapat membantu memenuhi kebutuhan tersebut dengan menggunakan analisis overlay (tumpangsusun peta), sehingga dihasilkan peta komposit sebagai gabungan dari sejumlah peta yang di tumpangsusunkan.

\section{Tujuan}

Tujuan dari penelitian ini adalah: 1) Pemetaan dan analisis sebaran stasiun hujan yang ada di Jawa Barat, kaitannya dengan ketinggian, fisiografi, dan curah hujan sehingga dapat terlihat merata tidaknya sebaran stasiun hujan yang ada; 2) Pemetaan dan analisis sebaran stasiun hujan berdasarkan zona fisiomorfohidro Jawa Barat; dan 3) Rasionalisasi pemilihan dan penentuan stasiun hujan yang dapat dijadikan wakil dari setiap unit lahan untuk kepentingan berbagai analisis hujan.

\section{METODE PENELITIAN}

Data curah hujan yang baik, akurat, representatif, dan proporsional diperoleh dari stasiun hujan yang secara geografis dan hidrologis juga representatif dan proporsional. Karena itu, diperlukan parameter-parameter yang dapat dijadikan indikator untuk menentukan apakah letak stasiun hujan itu representatif dan proporsional. Dalam kaitan ini penulis membuat peta Fisiomorfohidro untuk Jawa Barat berdasarkan parameter ketinggian tempat, fisiografi, dan isohyet. Karena itu, dibuat peta sesuai dengan parameterparameter tersebut sehingga peta yang harus dibuat adalah peta topografi, peta fisiografi, dan peta isohyet. Untuk keperluan tersebut digunakan Aplikasi Sistem Informasi Geografis (SIG) MapInfo.

Hasil tumpangsusun peta adalah peta komposit/gabungan yang tiap unit lahan di dalamnya merupakan gabungan dari kondisi morfologi, ketinggian, dan curah hujan. Untuk memudahkan, tiap unit lahan diberi kode. Contoh :

$\underline{B d} \underline{1} \underline{b}$

Simbol dua huruf pertama menunjukkan kondisi fisiografi

Simbol kedua menunjukkan kondisi curah hujan

Simbol ketiga menunjukkan topografi

Jika dibaca: Unit lahan yang termasuk wilayah fisiogtafi Zona Bandung dengan curah hujan antara 1000 - 1500 dan ketinggian 600-1000 meter di atas permukaan air laut. 
Tabel 1.

Klasifikasi Parameter dan Simbolisasi Fisiografi, Topografi, dan Isohyet.

\section{Parameter dan Simbol}

\begin{tabular}{cccccc}
\hline \multicolumn{1}{c}{ Fisiografi } & Simbol & Ketinggian & Simbol & Isohyet & Simbol \\
\hline $\begin{array}{l}\text { Daerah } \\
\text { Pantai Jakarta }\end{array}$ & $\mathrm{Jk}$ & $<600$ & $\mathrm{a}$ & $1000-1500$ & 1 \\
\hline Zona Bogor & $\mathrm{Bg}$ & $600-1000$ & $\mathrm{~b}$ & $1500-2000$ & 2 \\
\hline Zona Bandung & $\mathrm{Bd}$ & $1000-1500$ & $\mathrm{c}$ & $2000-2500$ & 3 \\
\hline $\begin{array}{c}\text { Zona } \\
\begin{array}{c}\text { Pegunungan } \\
\text { Selatan }\end{array}\end{array}$ & $\mathrm{Ps}$ & $>1500$ & $\mathrm{~d}$ & $2500-3000$ & 4 \\
\hline $\begin{array}{c}\text { Pegunungan } \\
\text { Bayah }\end{array}$ & $\mathrm{Pb}$ & & & $3000-3500$ & 5 \\
\hline & & & $3500-4000$ & 6 \\
\hline
\end{tabular}

Untuk lebih jelasnya, prosedur penentuan zona Fisiomorfohidro dapat dilihat pada gambar di bawah ini :

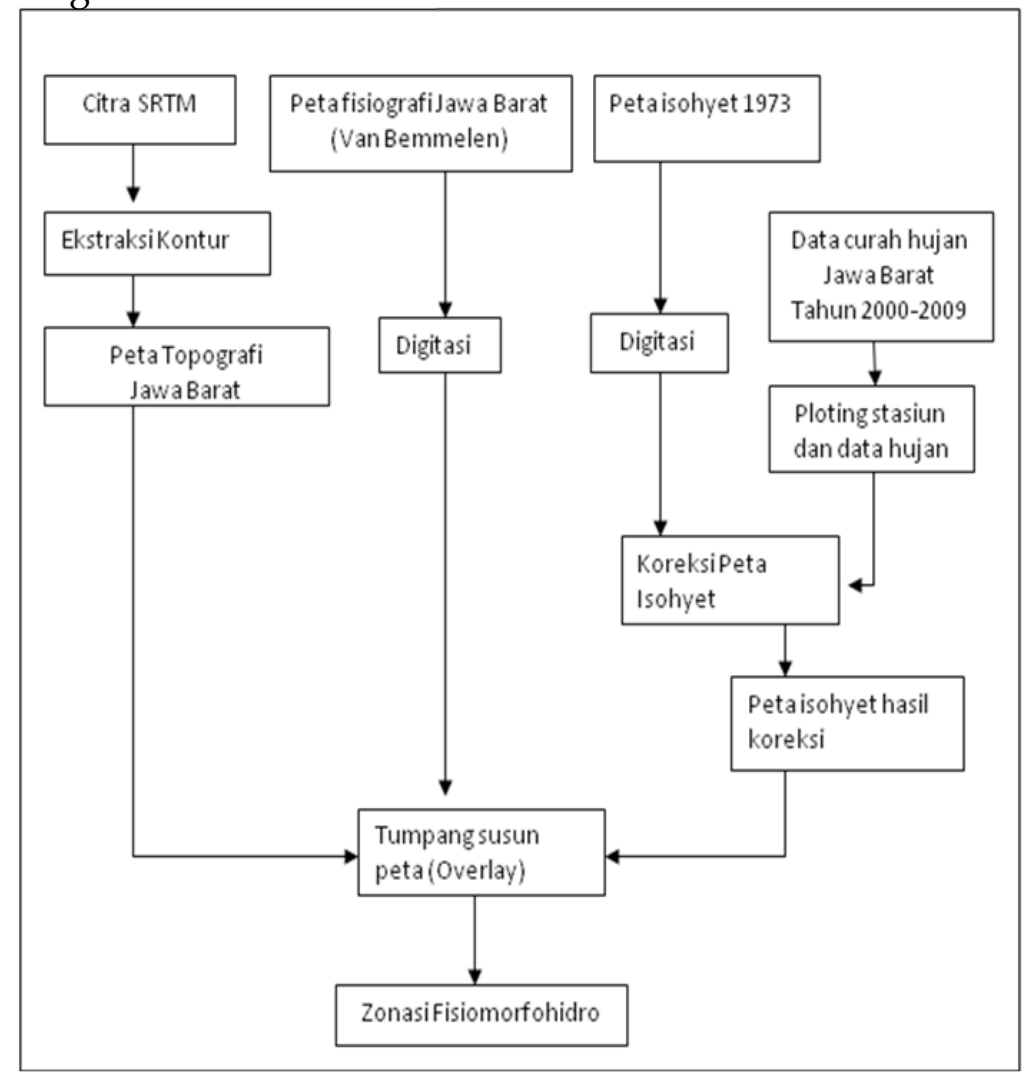

Gambar 1. Bagan Prosedur Penentuan Zone Fisiomorfohidro 
Gambar 1 menunjukkan prosedur penentuan zonasi fisiomorfohidro. Langkah-langkah dari kegiatan zonasi tersebut adalah:

Zonasi Topografi, peta yang menggambarkan ketinggian tempat atau disebut peta topografi diperoleh dari citra SRTM (Shuttle Radar Topography Mission) dengan klasifikasi ketinggian kurang dari 600 meter, 600-1000 meter, 1000-1500 meter, lebih dari 1500 meter.

Zonasi Fiografi Jawa Barat, peta fisiografi yang digunakan adalah yang dibuat oleh Van Bemmelen pada tahun 19. Peta tersebut membagi wilayah Jawa Barat menjadi 5 satuan fisiografi yaitu zona Jakarta, Zona Bogor, Zona Bandung, Zona Pegunungan Selatan, dan Zona Pegunungan Bayah.

Zonasi Sebaran Hujan (Isohyet), peta isohyet merupakan garis-garis imajiner di permukaan bumi yang menggambarkan curah hujan yang sama. Peta ini merupakan hasil interpolasi data curah hujan yang ada pada sejumlah stasiun hujan di wilayah yang dipetakan. Peta isohyet yang dijadikan dasar adalah peta isohyet yang dibuat pada tahun 1973 oleh Lembaga Meteorologi dan Geofisika Departemen Perhubungan Jakarta. Peta tersebut dijadikan dasar untuk dikoreksi dengan data curah hujan tahunan terbaru tahun 2000-2009.

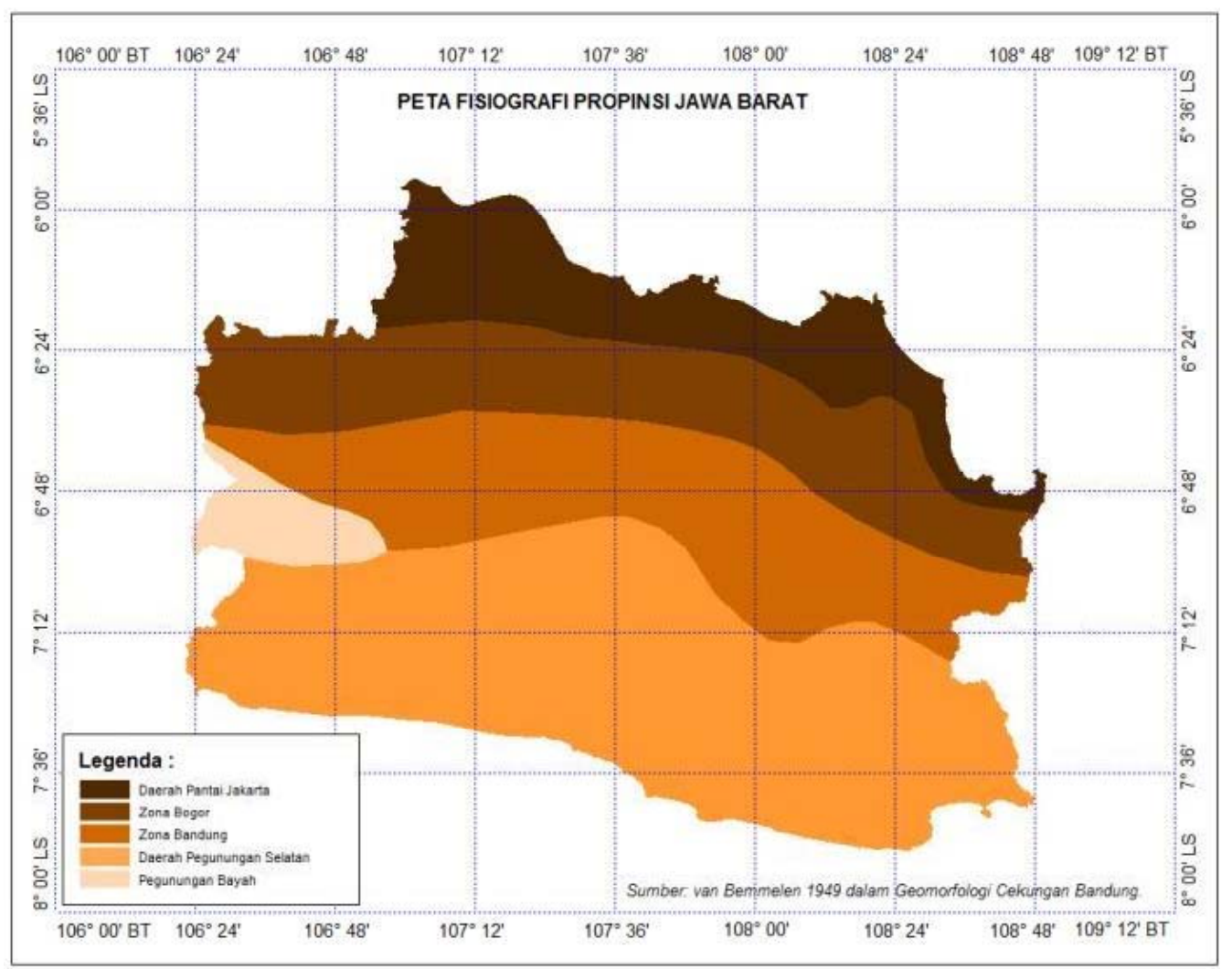

Gambar 2. Peta Fisiografi Propinsi Jawa Barat 


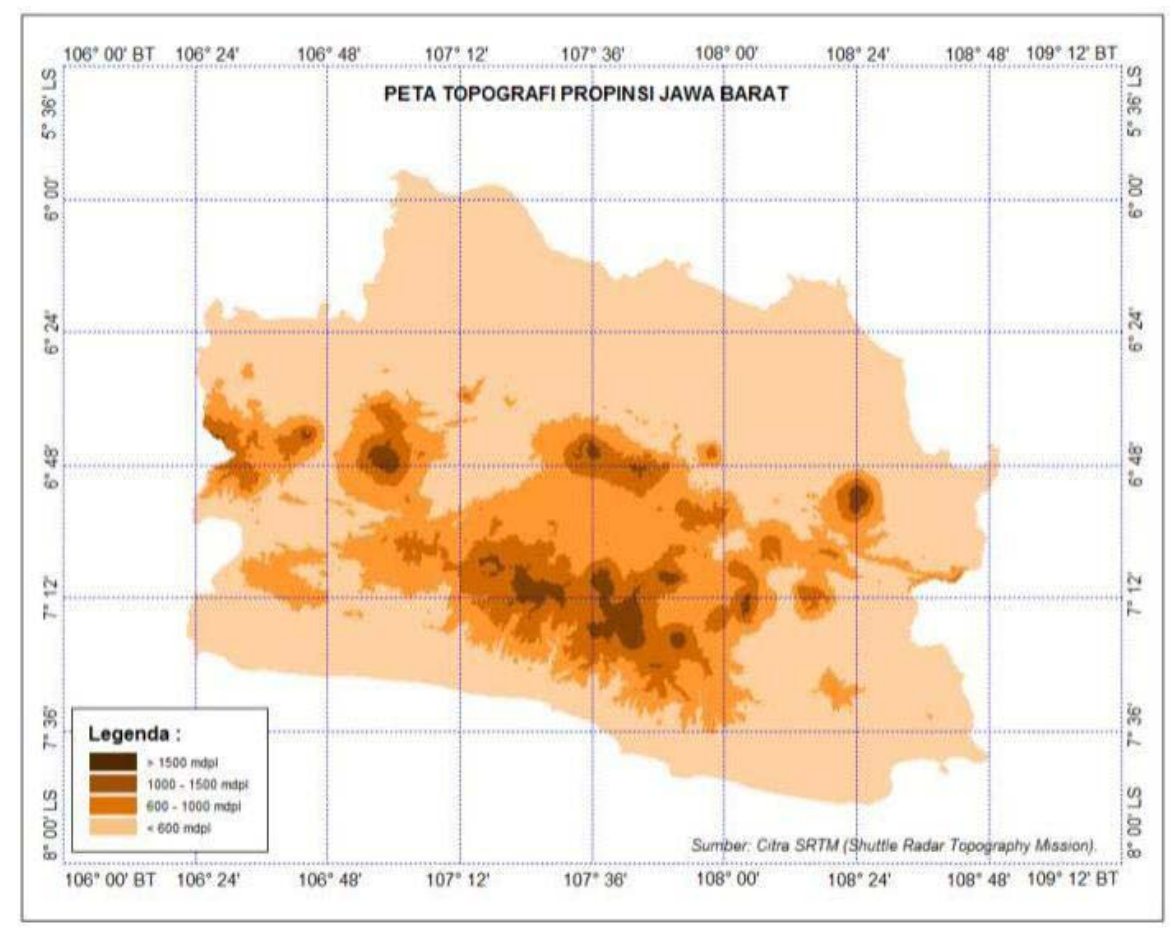

Gambar 3. Peta Topografi Propinsi Jawa Barat

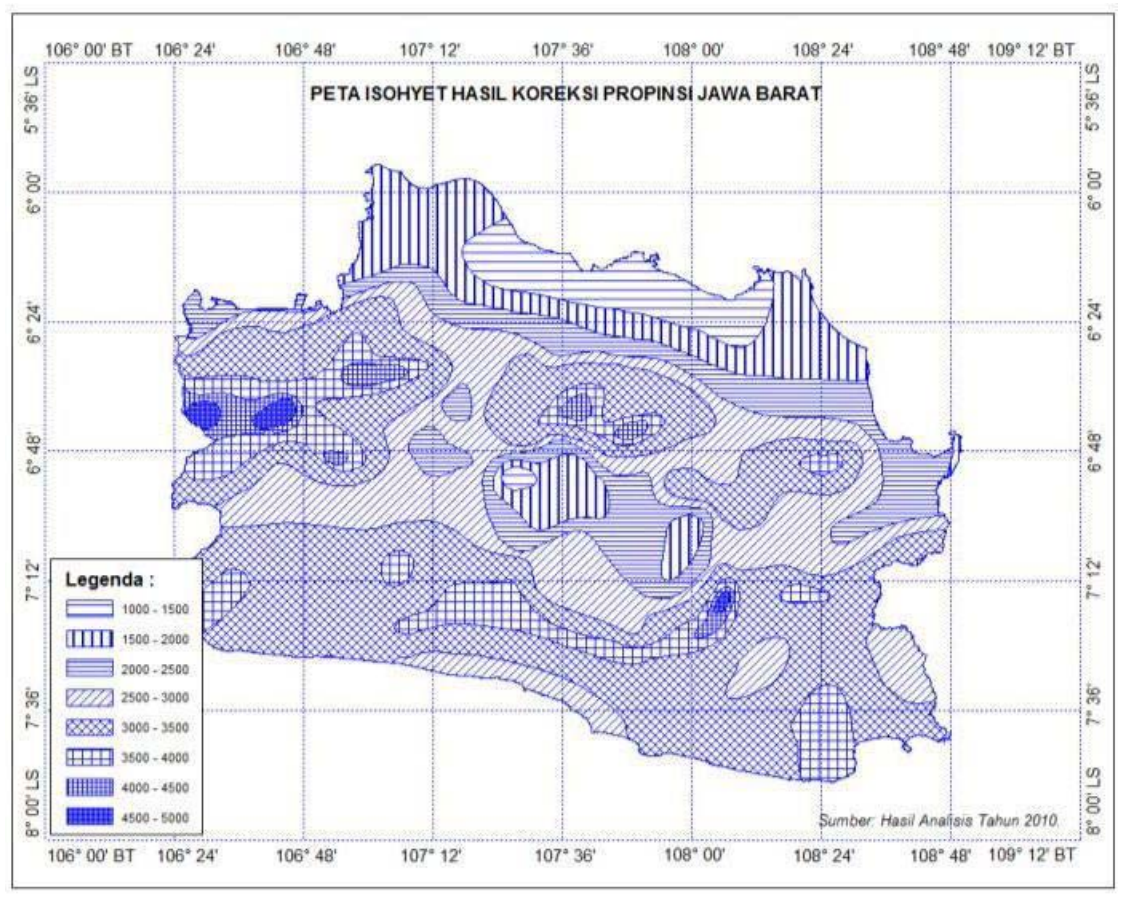

Gambar 4. Peta Sebaran Hujan (Isohyet) Propinsi Jawa Barat 
Langkah berikutnya adalah overlay peta. Peta yang di-overlay-kan terdiri atas peta topografi, peta fisiografi, dan peta isohyet yang telah dibuat sebelumnya. Untuk keperluan tersebut digunakan Aplikasi Sistem Informasi Geografis (SIG) dengan software MapInfo. Hasil overlay peta adalah peta komposit/gabungan yang tiap unit lahan di dalamnya merupakan gabungan dari kondisi morfologi, ketinggian, dan curah hujan yang diberi nama sebagai peta zonasi wilayah Fisiomorfohidro. Hasilnya Jawa Barat terbagi ke dalam beberapa wilayah fisiomorfohidro yang terbagi ke dalam 90 zona. Setiap zona memiliki karakteristik yang khas ditinjau dari aspek fisiografi, topografi, dan sebaran curah hujan/isohyet.

Setelah zonasi fisiomorfohidro selesai dibuat, maka dilakukan plotting stasiun hujan sesuai dengan koordinat stasiun hujan yang telah diperoleh datanya dan kemudian menumpangsusunkan hasil plotting tersebut dengan zona fisiomorfohidro Jawa Barat. Berdasarkan data stasiun hujan yang didapat dari Dinas Pengelolaan Sumber Daya Air (PSDA) Propinsi Jawa Barat, setidaknya terdapat 173 stasiun hujan di Jawa Barat yang terangkum dalam beberapa wilayah sungai. Penulis meyakini, bahwa masih banyak stasiun hujan lain yang belum terinventarisir. Dari 173 stasiun hujan yang diketahui, hanya 100 stasiun hujan yang dapat dipetakan dikurangi dengan 9 stasiun hujan yang tidak memiliki data curah hujan. Jadi tepatnya hanya 91 stasiun hujan yang dapat dipetakan dan memiliki data curah hujan.

Pada umumnya, stasiun hujan di Jawa Barat menggunakan alat ukur hujan manual. Hanya beberapa tempat saja (kurang dari sepuluh yang diketahui) stasiun hujan yang memiliki alat ukur hujan otomatis. Hasil pencatatan alat ukur hujan biasanya dicatat menjadi data curah hujan harian, sehingga sangat sulit jika memerlukan data curah hujan pada durasi menit dan beberapa jam saja. Hal ini menjadi kendala tersendiri bagi beberapa peneliti yang memerlukan data hujan dengan durasi menit atau jam. Beberapa stasiun hujan di Jawa Barat yang diketahui memiliki alat ukur hujan otomatis diantaranya stasiun Cemara di Bandung, stasiun Citalang, Plered, dan Sukatani di Jatiluhur, stasiun Citeko di Bogor, dan stasiun Sukamandi di Subang. Sangat dimungkinkan bahwa masih ada beberapa stasiun otomatis lainnya di Jawa Barat, walaupun kemungkinannya kecil. Beberapa stasiun yang teridentifikasi di atas dapat menjadi acuan untuk beberapa orang/instansi yang membutuhkan data curah hujan pada durasi menit dan jam. 


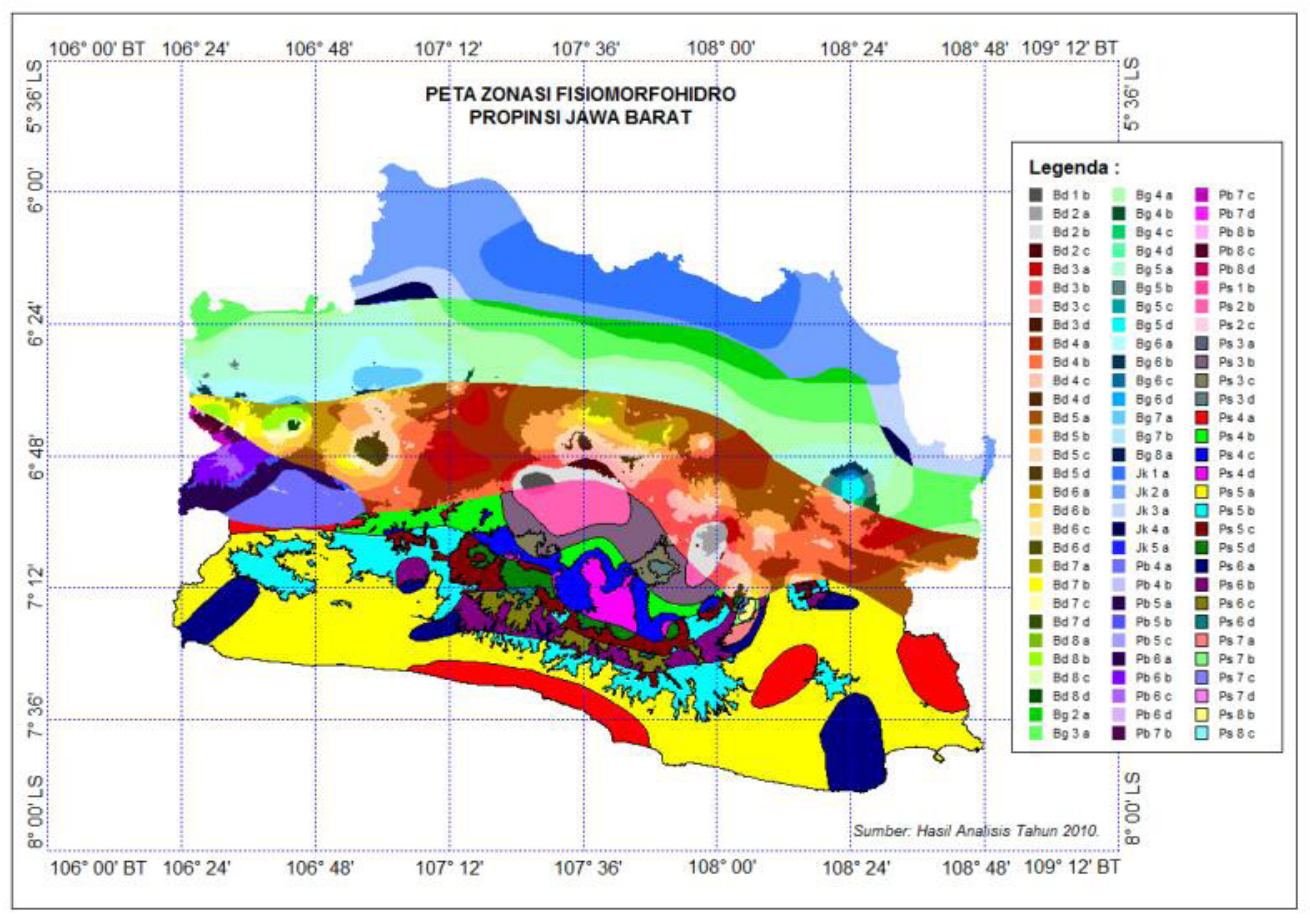

Gambar 5. Peta Zonasi Wilayah Fisiomorfohidro Propinsi Jawa Barat

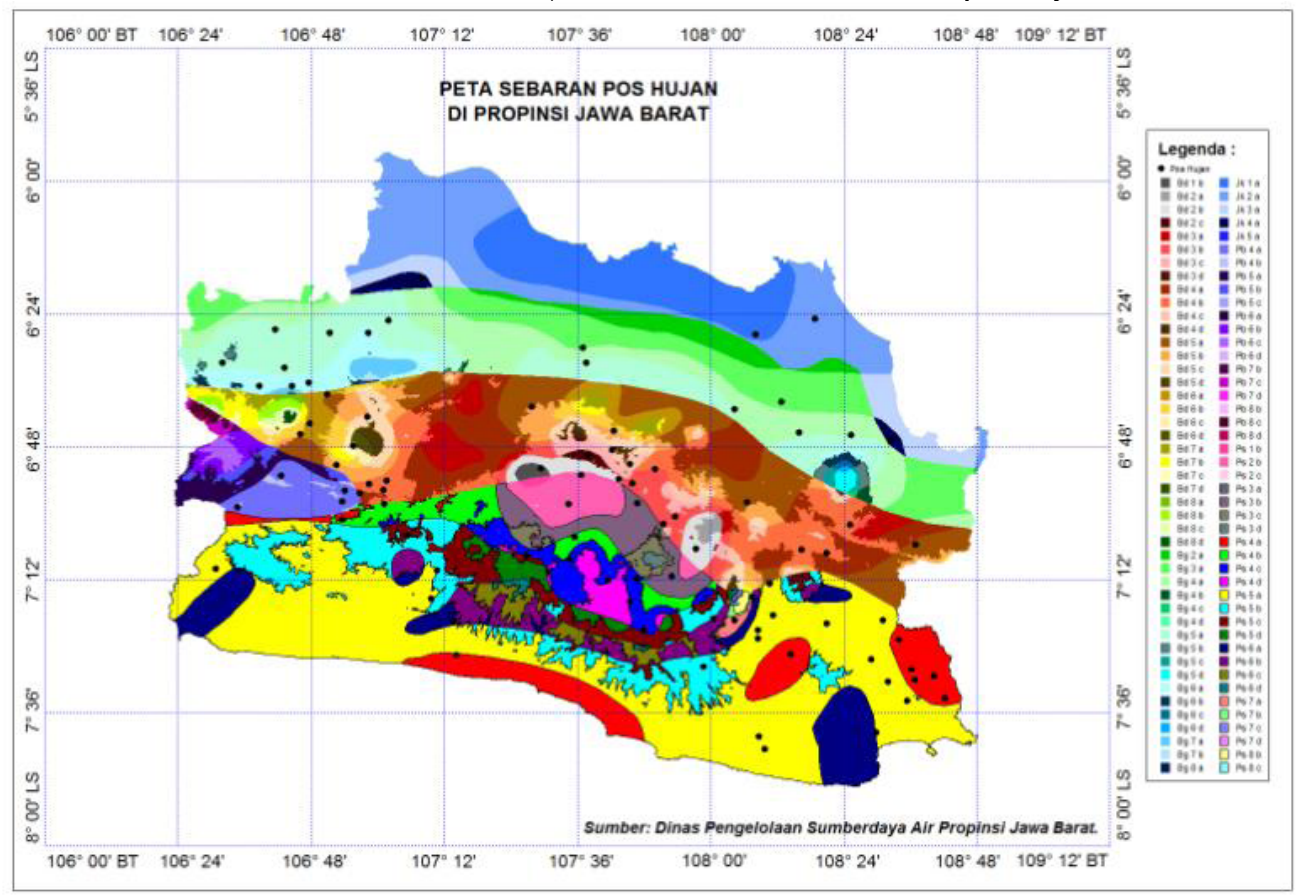

Gambar 6. Peta Sebaran Pos Hujan di Propinsi Jawa Barat Berdasarkan Zonasi Fisiomorfohidro 
Pada tabel 2 disajikan beberapa nama stasiun yang dapat dipetakan dan memiliki data curah hujan dengan alat ukur curah hujan manual.

Tabel 2.

Daftar Nama Stasiun yang Dapat Dipetakan dan Memiliki Data Curah Hujan

\begin{tabular}{l|l|} 
NO & NAMA STASIUN \\
\hline 1 & Cibanteng Hilir \\
\hline 3 & Klapanunggal \\
\hline 4 & Katulampa \\
\hline 5 & Perk. Kuripan \\
\hline 6 & Pasir Jaya \\
\hline 7 & Kranji \\
\hline 8 & Tunggilis \\
\hline 9 & Cigudeg \\
\hline 10 & Cibanteng Hulu \\
\hline 11 & Bd.Cikarang \\
\hline 12 & Empang \\
\hline 13 & Sentral \\
\hline 14 & Citarik \\
\hline 15 & Ciraden \\
\hline 16 & Batu Karut \\
\hline 17 & Cicurug \\
\hline 18 & Sukanegara \\
\hline 19 & Geger Bitung \\
\hline 20 & Manggis \\
\hline 21 & Cibadak \\
\hline 22 & St. Ciaul \\
\hline 23 & Cisalada \\
\hline
\end{tabular}

\begin{tabular}{|l|l|} 
NO & NAMA STASIUN \\
\hline 24 & Gn. Puyuh \\
\hline 25 & Dinas Pengairan \\
\hline 26 & Cimandiri \\
\hline 27 & Ciletuh \\
\hline 28 & Pagelaran \\
\hline 29 & Citoe \\
\hline 30 & Cidaun \\
\hline 31 & Cidamar \\
\hline 32 & Kayu Ambon \\
\hline 33 & Cibeureum \\
\hline 34 & Cisondari \\
\hline 35 & Cisomang \\
\hline 36 & Jatiroke \\
\hline 37 & Ciherang \\
\hline 38 & Cisalak \\
\hline 39 & Ciluluk \\
\hline 40 & Cisampih \\
\hline 41 & Cipeusing \\
\hline 42 & Margahayu I \\
\hline 43 & Cipanas \\
\hline 44 & Cicalengka \\
\hline 45 & Rancaekek \\
\hline 46 & Cibiru \\
\hline & \\
\hline
\end{tabular}

\begin{tabular}{|l|l|}
\hline NO & NAMA STASIUN \\
\hline 47 & Cileunca \\
\hline 48 & Lembang \\
\hline 49 & Tanjungsari \\
\hline 50 & Dago Pakar \\
\hline 51 & Cipaku \\
\hline 52 & Pamegatan \\
\hline 53 & Tarogong \\
\hline 54 & Pangauban \\
\hline 55 & Leuwi Goong \\
\hline 56 & Kepakan \\
\hline 57 & Jamblang \\
\hline 58 & Ciwaru \\
\hline 59 & Ujungjaya \\
\hline 60 & Pamulihan \\
\hline 61 & Cipasang \\
\hline 62 & Rentang \\
\hline 63 & Argapura \\
\hline 64 & Sumurwatu \\
\hline 65 & Jatbarang \\
\hline 66 & Jatiwangi \\
\hline 67 & Darma \\
\hline 68 & Parigi \\
\hline 69 & Singaparna \\
\hline & \\
\hline 56
\end{tabular}

\begin{tabular}{|l|l|} 
NO & NAMA STASIUN \\
\hline 70 & Cikunten II \\
\hline 71 & Gn.Satria \\
\hline 72 & Pangkalan \\
\hline 73 & Kawalu \\
\hline 74 & Karangnunggal \\
\hline 75 & Padawaras \\
\hline 76 & Taraju \\
\hline 77 & Cigede \\
\hline 78 & Cihonje \\
\hline 79 & Panjalu \\
\hline 80 & Panawangan \\
\hline 81 & Cms Kota \\
\hline 82 & Rawa Onom \\
\hline 83 & Padaringan \\
\hline 84 & Gn.Putri I \\
\hline 85 & Gn.Putri II \\
\hline 86 & Ciputrahaji \\
\hline 87 & Padaherang \\
\hline 88 & Citalahab \\
\hline 89 & Cikembulan \\
\hline 90 & Cimulu \\
\hline 91 & Cibatukurung \\
\hline & \\
\hline
\end{tabular}

Sumber : Dinas Pengelolaan Sumber Daya Air Propinsi Jawa Barat, Tahun 2010.

\section{HASIL DAN PEMBAHASAN}

Data stasiun hujan yang menjadi acuan dalam penelitian ini adalah data yang bersumber dari Dinas Pengelolaan Sumber Daya Air Propinsi Jawa Barat tahun 2010 yang dapat dipetakan dan tercatat memiliki jumlah curah hujan tahunan. Kendala beberapa data stasiun hujan lain yang tidak dapat dipetakan adalah karena posisi stasiun hujan atau koordinat stasiun hujan yang tidak tercatat. Bahkan setelah melakukan survei lapangan, terdapat ketimpangan antara koordinat yang tercatat dengan lokasi sebenarnya di lapangan.

Pada umumnya, persebaran stasiun hujan tidak merata. Persebaran stasiun hujan lebih banyak terpusat pada satu zona, sehingga pada zona lainnya hanya sedikit bahkan tidak memiliki stasiun hujan pewakil. Sedangkan pada zona yang memiliki jumlah stasiun hujan lebih banyak, terdapat kelebihan jumlah stasiun hujan dari jumlah ideal yang ditentukan. 
Hasil overlay peta sebaran stasiun hujan kemudian di overlay-kan dengan peta fisiografi menunjukkan bahwa stasiun hujan di Jawa Barat tersebar di semua zona tetapi tidak merata. Persebaran stasiun hujan lebih banyak terdapat di Zona Daerah Pegunungan Selatan. Sedangkan untuk bagian utara Jawa Barat sendiri yaitu Daerah Pantai Jakarta hanya memiliki 4 stasiun hujan pewakil dan Zona Bogor 15 stasiun hujan. Analisis berdasarkan overlay zona fisiografi juga menunjukkan bahwa jumlah stasiun hujan aktual lebih banyak tersebar dibandingkan dengan jumlah ideal per $1000 \mathrm{~km}^{2}$ yang seharusnya. Jika dilihat secara keseluruhan, antara jumlah stasiun aktual dan ideal per $1000 \mathrm{~km}^{2}$ terdapat kelebihan stasiun hujan sebanyak 54 stasiun hujan (lihat Tabel 3).

Tabel 3.

Jumlah dan Kerapatan Stasiun Hujan di Jawa Barat Berdasarkan Zonasi Fisiografi

\begin{tabular}{lcccc}
\hline \multicolumn{1}{c}{ Fisiografi } & Luas $\left.\mathbf{( k m}^{\mathbf{2}}\right)$ & $\begin{array}{c}\text { Jumlah stasiun } \\
\text { hujan aktual }\end{array}$ & Ideal per $\mathbf{1 0 0 0} \mathbf{k m}^{\mathbf{2}}$ & Keterangan \\
\hline Daerah Pantai Jakarta & 5.081 & 4 & 5 & Kurang 1 \\
\hline Zona Bogor & 7.470 & 15 & 8 & Lebih 8 \\
\hline Zona Bandung & 8.293 & 27 & 15 & Lebih 19 \\
\hline $\begin{array}{l}\text { Zona Pegunungan } \\
\text { Selatan }\end{array}$ & 15.090 & 41 & 1 & Lebih 26 \\
\hline Pegunungan Bayah & 1.272 & 4 & 37 & Lebih 3 \\
\hline \multicolumn{1}{c}{ Total } & 37.206 & 91 & Lebih 54 \\
\hline
\end{tabular}

Sumber: Hasil Analisis Tahun 2010

Persebaran stasiun hujan berdasarkan zonasi topografi menunjukkan bahwa stasiun hujan lebih banyak tersebar pada zona topografi $<600 \mathrm{~m} \mathrm{dpl}$ dengan jumlah stasiun tersebar 51, sedangkan jumlah ideal per $1000 \mathrm{~km}^{2}$ adalah 26 stasiun hujan. Artinya pada zona ini terdapat kelebihan stasiun hujan sebanyak 25 stasiun yang tersebar. Pada zona topografi $>1500 \mathrm{~m}$ dpl terdapat kesesuaian antara jumlah stasiun aktual dengan jumlah ideal per $1000 \mathrm{~km}^{2}$. Jika dilihat secara keseluruhan, antara jumlah stasiun aktual dan ideal per $1000 \mathrm{~km}^{2}$ terdapat kelebihan stasiun hujan sebanyak 53 stasiun hujan (lihat Tabel 4).

Tabel 4.

Jumlah dan Kerapatan Stasiun Hujan di Jawa Barat Berdasarkan Zonasi Topografi

\begin{tabular}{lcccc}
\hline Topografi & Luas $\left(\mathbf{k m}^{\mathbf{2}}\right)$ & $\begin{array}{c}\text { Jumlah stasiun } \\
\text { hujan aktual }\end{array}$ & Ideal per 1000 $\mathbf{k m}^{2}$ & Keterangan \\
\hline$<600$ & 26.040 & 51 & 26 & Lebih 25 \\
\hline $600-1000$ & 7.556 & 27 & 8 & Lebih 20 \\
\hline $1000-1500$ & 2.740 & 12 & 3 & Lebih 10 \\
\hline$>1500$ & 873,80 & 1 & 1 & Sesuai \\
\hline Total & 37.210 & 91 & 38 & Lebih 53 \\
\hline
\end{tabular}

Sumber : Hasil Analisis Tahun 2010 
Persebaran stasiun hujan berdasarkan zonasi isohyet menunjukkan bahwa stasiun hujan lebih banyak tersebar pada zona isohyet 2500 - 3000 dengan selisih aktual dan ideal adalah stasiun hujan pewakil pada zona ini lebih 26 stasiun hujan. Sedangkan pada zona 1000 - 2000 dan 4500 - 5000 terdapat kekurangan 1 stasiun hujan dari jumlah idealnya. Dilihat secara keseluruhan, antara jumlah stasiun aktual dan ideal per $1000 \mathrm{~km}^{2}$ terdapat kelebihan stasiun hujan sebanyak 52 stasiun hujan (lihat Tabel 5).

Tabel 5.

Jumlah dan Kerapatan Stasiun Hujan di Jawa Barat

Berdasarkan Zonasi Isohyet

\begin{tabular}{ccccc}
\hline Topografi & Luas $\left.\mathbf{( k m}^{\mathbf{2}}\right)$ & $\begin{array}{c}\text { Jumlah stasiun } \\
\text { hujan aktual }\end{array}$ & Ideal per $\mathbf{1 0 0 0} \mathbf{k m}^{\mathbf{2}}$ & Keterangan \\
\hline $1000-1500$ & 1.840 & 2 & 3 & Kurang 1 \\
\hline $1500-2000$ & 4.025 & 6 & 4 & Lebih 2 \\
\hline $2000-2500$ & 4.366 & 8 & 4 & Lebih 4 \\
\hline $2500-3000$ & 8.238 & 34 & 8 & Lebih 26 \\
\hline $3000-3500$ & 14.130 & 28 & 14 & Lebih 14 \\
\hline $3500-4000$ & 3.699 & 11 & 4 & Lebih 7 \\
\hline $4000-4500$ & 697,2 & 2 & 1 & Lebih 14 \\
\hline $4500-5000$ & 214,7 & - & 1 & Kurang 1 \\
\hline Total & 37.210 & 91 & 39 & Lebih 52 \\
\hline
\end{tabular}

Sumber : Hasil Analisis Tahun 2010

Berdasarkan hasil overlay peta zonasi wilayah fisiomorfohidro dan peta persebaran stasiun hujan di Jawa Barat, maka diketahui bahwa masih banyak zonasi-zonasi wilayah yang belum memiliki stasiun hujan pewakil. Kriteria penentuan ideal untuk zonasi wilayah fisiomorfohidro adalah $10-1000 \mathrm{~km}^{2}$, hal ini dikarenakan zonasi wilayah yang lebih spesifik dari ketiga aspek fisiografi, topografi, dan isohyet. Karena persebaran stasiun hujan lebih banyak tersebar di Jawa Barat bagian selatan, maka zonasi-zonasi wilayah yang tidak memiliki stasiun hujan pewakil banyak tersebar di Jawa Barat bagian tengah dan utara. Beberapa zonasi wilayah yang tidak memiliki stasiun hujan pewakil diantaranya zona Bd3a, Bd7a, Bg2a, Bg6b, Bg7b, Bg6c, Bg5d, Bg6d, Jk3a, Pb8c, Ps1b, Ps6a, dan masih banyak lagi. Stasiun hujan banyak tersebar pada zona Ps5a dengan stasiun hujan pewakil sebanyak 15 stasiun, sedangkan jumlah idealnya adalah 6 stasiun hujan. 
Tabel 6.

Jumlah dan Kerapatan Stasiun Hujan di Jawa Barat Berdasarkan Zonasi Fisiomorfohidro

\begin{tabular}{|c|c|c|c|c|}
\hline Morfohidrometri & Luas $\left(\mathrm{km}^{2}\right)$ & $\begin{array}{c}\text { Jumlah Stasiun } \\
\text { Hujan Aktual }\end{array}$ & $\begin{array}{c}\text { Ideal } 1 \text { per } \\
10-1000 \mathrm{~km}^{2}\end{array}$ & Keterangan \\
\hline $\mathrm{Bd} 1 \mathrm{~b}$ & 46,40 & 1 & 1 & Sesuai \\
\hline $\mathrm{Bd} 2 \mathrm{a}$ & 59,40 & 0 & 1 & Kurang 1 \\
\hline $\mathrm{Bd} 2 \mathrm{~b}$ & 265,40 & 2 & 1 & Lebih 1 \\
\hline $\mathrm{Bd} 2 \mathrm{C}$ & 38,03 & 1 & 1 & Sesuai \\
\hline $\mathrm{Bd} 3 \mathrm{a}$ & 480,50 & 0 & 1 & Kurang 1 \\
\hline $\mathrm{Bd} 3 \mathrm{~b}$ & 403,10 & 3 & 1 & Lebih 2 \\
\hline $\mathrm{Bd} 3 \mathrm{C}$ & 165,50 & 0 & 1 & Kurang 1 \\
\hline $\mathrm{Bd} 3 \mathrm{~d}$ & 11,68 & 0 & 1 & Kurang 1 \\
\hline $\mathrm{Bd} 4 \mathrm{a}$ & $1.575,00$ & 1 & 2 & Kurang 1 \\
\hline $\mathrm{Bd} 4 \mathrm{~b}$ & 989,20 & 7 & 1 & Lebih 6 \\
\hline $\mathrm{Bd} 4 \mathrm{C}$ & 213,60 & 2 & 1 & Lebih 1 \\
\hline $\mathrm{Bd} 4 \mathrm{~d}$ & 30,93 & 0 & 1 & Kurang 1 \\
\hline Bd5a & $1.551,00$ & 2 & 2 & Sesuai \\
\hline $\mathrm{Bd} 5 \mathrm{~b}$ & 778,60 & 3 & 1 & Lebih 2 \\
\hline $\mathrm{Bd} 5 \mathrm{C}$ & 297,50 & 1 & 1 & Sesuai \\
\hline $\mathrm{Bd} 5 \mathrm{~d}$ & 96,08 & 0 & 1 & Kurang 1 \\
\hline Bd $6 \mathrm{a}$ & 329,00 & 3 & 1 & Lebih 2 \\
\hline $\mathrm{Bd} 6 \mathrm{~b}$ & 291,80 & 0 & 1 & Kurang 1 \\
\hline $\mathrm{Bd} 6 \mathrm{C}$ & 78,96 & 1 & 1 & Sesuai \\
\hline $\mathrm{Bd} 6 \mathrm{~d}$ & 39,50 & 0 & 1 & Kurang 1 \\
\hline $\mathrm{Bd} 7 \mathrm{a}$ & 180,30 & 0 & 1 & Kurang 1 \\
\hline $\mathrm{Bd} 7 \mathrm{~b}$ & 187,50 & 0 & 1 & Kurang 1 \\
\hline $\mathrm{Bd} 7 \mathrm{C}$ & 40,57 & 0 & 1 & Kurang 1 \\
\hline $\mathrm{Bd} 7 \mathrm{~d}$ & 3,28 & 0 & 0 & Sesuai \\
\hline $\mathrm{Bd} 8 \mathrm{a}$ & 13,32 & 0 & 1 & Kurang 1 \\
\hline $\mathrm{Bd} 8 \mathrm{~b}$ & 85,79 & 0 & 1 & Kurang 1 \\
\hline $\mathrm{Bd} 8 \mathrm{C}$ & 36,19 & 0 & 1 & Kurang 1 \\
\hline $\mathrm{Bd} 8 \mathrm{~d}$ & 8,32 & 0 & 0 & Sesuai \\
\hline $\mathrm{Bg} 2 \mathrm{a}$ & 534,90 & 0 & 1 & Kurang 1 \\
\hline $\mathrm{Bg} 3 \mathrm{a}$ & $1.904,00$ & 2 & 2 & Sesuai \\
\hline $\mathrm{Bg} 4 \mathrm{a}$ & $1.868,00$ & 3 & 2 & Lebih 1 \\
\hline $\mathrm{Bg} 4 \mathrm{~b}$ & 23,21 & 0 & 1 & Kurang 1 \\
\hline $\mathrm{Bg} 4 \mathrm{C}$ & 3,79 & 0 & 0 & Sesuai \\
\hline $\mathrm{Bg} 4 \mathrm{~d}$ & 1,02 & 0 & 0 & Sesuai \\
\hline $\mathrm{Bg} 5 \mathrm{a}$ & $2.192,00$ & 6 & 2 & Lebih 4 \\
\hline $\mathrm{Bg} 5 \mathrm{~b}$ & 66,29 & 0 & 1 & Kurang 1 \\
\hline $\mathrm{Bg} 5 \mathrm{C}$ & 33,73 & 0 & 1 & Kurang 1 \\
\hline $\mathrm{Bg} 5 \mathrm{~d}$ & 41,31 & 0 & 1 & Kurang 1 \\
\hline $\mathrm{Bg} 6 \mathrm{a}$ & 546,20 & 4 & 1 & Lebih 3 \\
\hline $\mathrm{Bg} 6 \mathrm{~b}$ & 79,00 & 0 & 1 & Kurang 1 \\
\hline $\mathrm{Bg} 6 \mathrm{C}$ & 12,96 & 0 & 1 & Kurang 1 \\
\hline $\mathrm{Bg} 6 \mathrm{~d}$ & 4,46 & 0 & 0 & Sesuai \\
\hline $\mathrm{Bg} 7 \mathrm{a}$ & 147,00 & 0 & 1 & Kurang 1 \\
\hline $\mathrm{Bg} 7 \mathrm{~b}$ & 10,24 & 0 & 1 & Kurang 1 \\
\hline $\mathrm{Bg} 8 \mathrm{a}$ & 0,41 & 0 & 0 & Sesuai \\
\hline
\end{tabular}

\begin{tabular}{|c|c|c|c|c|}
\hline Morfohidrometri & Luas $\left(\mathrm{km}^{2}\right)$ & $\begin{array}{c}\text { Jumlah Stasiun } \\
\text { Hujan Aktual }\end{array}$ & $\begin{array}{c}\text { Ideal } 1 \text { per } \\
10-1000 \mathrm{~km}^{2}\end{array}$ & Keterangan \\
\hline Jk1 a & $1.766,00$ & 1 & \begin{tabular}{|l|}
2 \\
\end{tabular} & Kurang 1 \\
\hline Jk $2 a$ & $2.611,00$ & 1 & 3 & Kurang 2 \\
\hline Jk 3 a & 557,40 & 0 & 1 & Kurang 1 \\
\hline Jk 4 a & 143,30 & 2 & 1 & Lebih 1 \\
\hline Jk 5 a & 3,08 & 0 & 0 & Sesuai \\
\hline $\mathrm{Pb} 4 \mathrm{a}$ & 542,60 & 4 & 1 & Lebih 3 \\
\hline $\mathrm{Pb} 4 \mathrm{~b}$ & 23,35 & 0 & 1 & Kurang 1 \\
\hline $\mathrm{Pb} 5 \mathrm{a}$ & 293,70 & 0 & 1 & Kurang 1 \\
\hline $\mathrm{Pb} 5 \mathrm{~b}$ & 74,27 & 0 & 1 & Kurang 1 \\
\hline $\mathrm{Pb} 5 \mathrm{C}$ & 0,77 & 0 & 0 & Sesuai \\
\hline $\mathrm{Pb} 6 \mathrm{a}$ & 18,87 & 0 & 1 & Kurang 1 \\
\hline $\mathrm{Pb} 6 \mathrm{~b}$ & 149,00 & 0 & 1 & Kurang 1 \\
\hline $\mathrm{Pb} 6 \mathrm{C}$ & 75,58 & 0 & 1 & Kurang 1 \\
\hline $\mathrm{Pb} 6 \mathrm{~d}$ & 0,93 & 0 & 0 & Sesuai \\
\hline $\mathrm{Pb} 7 \mathrm{~b}$ & 17,94 & 0 & 1 & Kurang 1 \\
\hline $\mathrm{Pb} 7 \mathrm{C}$ & 28,33 & 0 & 1 & Kurang 1 \\
\hline $\mathrm{Pb} 7 \mathrm{~d}$ & 1,13 & 0 & 0 & Sesuai \\
\hline $\mathrm{Pb} 8 \mathrm{~b}$ & 2,81 & 0 & 0 & Sesuai \\
\hline $\mathrm{Pb} 8 \mathrm{C}$ & 35,22 & 0 & 1 & Kurang 1 \\
\hline $\mathrm{Pb} 8 \mathrm{~d}$ & 7,74 & 0 & 0 & Sesuai \\
\hline Ps $1 \mathrm{~b}$ & 27,42 & 0 & 1 & Kurang 1 \\
\hline $\mathrm{Ps} 2 \mathrm{~b}$ & 513,50 & 2 & 1 & Lebih 1 \\
\hline Ps 2C & 2,17 & 0 & 0 & Sesuai \\
\hline Ps $3 a$ & 0,01 & 0 & 0 & Sesuai \\
\hline Ps 3 b & 641,70 & 2 & 1 & Lebih 1 \\
\hline Ps $3 \mathrm{C}$ & 168,10 & 0 & 1 & Kurang 1 \\
\hline Ps 3d & 32,05 & 0 & 1 & Kurang 1 \\
\hline Ps $4 a$ & $1.366,00$ & 7 & 2 & Lebih 5 \\
\hline Ps $4 \mathrm{~b}$ & 585,70 & 3 & 1 & Lebih 2 \\
\hline Ps 4c & 578,50 & 6 & 1 & Lebih 5 \\
\hline Ps 4d & 293,90 & 1 & 1 & Sesuai \\
\hline Ps $5 a$ & $6.161,00$ & 15 & 6 & Lebih 9 \\
\hline Ps 5b & $1.664,00$ & 2 & 2 & Sesuai \\
\hline Ps $5 c$ & 624,20 & 0 & 1 & Kurang 1 \\
\hline Ps 5d & 255,30 & 0 & 1 & Kurang 1 \\
\hline Ps 6a & $1.142,00$ & 0 & 1 & Kurang 1 \\
\hline Ps $6 \mathrm{~b}$ & 585,50 & 1 & 1 & Sesuai \\
\hline Ps $6 \mathrm{C}$ & 299,90 & 0 & 1 & Kurang 1 \\
\hline Ps $6 d$ & 45,43 & 0 & 1 & Kurang 1 \\
\hline Ps 7 a & 51,81 & 1 & 1 & Sesuai \\
\hline Ps $7 \mathrm{~b}$ & 20,36 & 1 & 1 & Sesuai \\
\hline Ps 7 C & 8,02 & 0 & 0 & Sesuai \\
\hline Ps $7 d$ & 0,71 & 0 & 0 & Sesuai \\
\hline Ps $8 b$ & 22,99 & 0 & 1 & Kurang 1 \\
\hline Ps $8 \mathrm{C}$ & 1,89 & 0 & 0 & Sesuai \\
\hline Total & 37.210 & 91 & 88 & \begin{tabular}{|l|} 
Lebih 3 \\
\end{tabular} \\
\hline
\end{tabular}

Sumber: Hasil Analisis Tahun 2010 


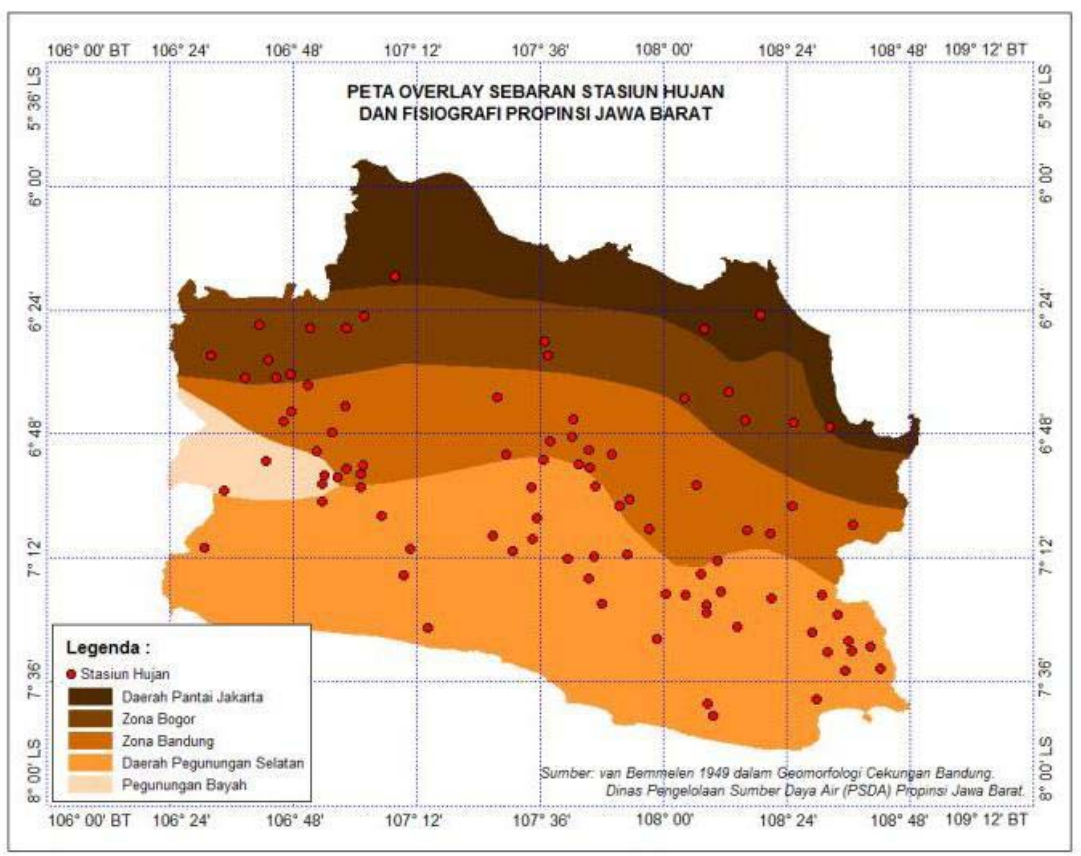

Gambar 7. Peta Hasil Overlay Sebaran Stasiun Hujan dan Fisiografi Propinsi Jawa Barat

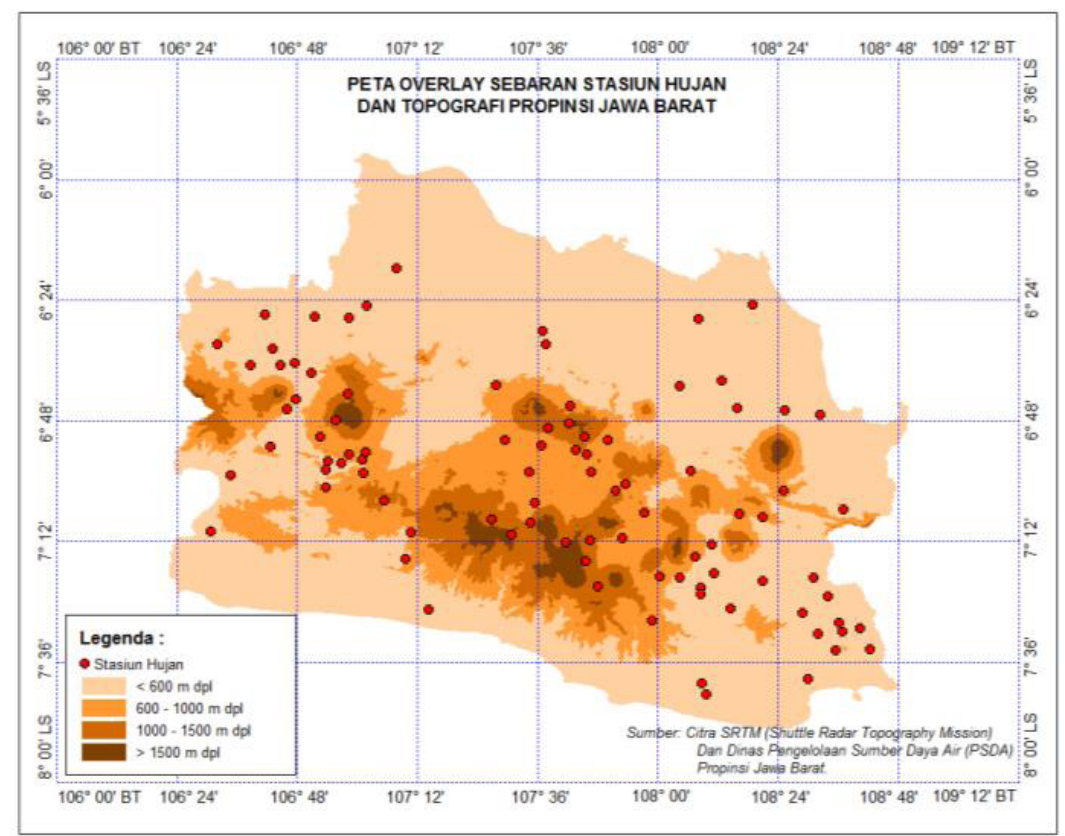

Gambar 8. Peta Hasil Overlay Sebaran Stasiun Hujan dan Topografi Propinsi Jawa Barat 


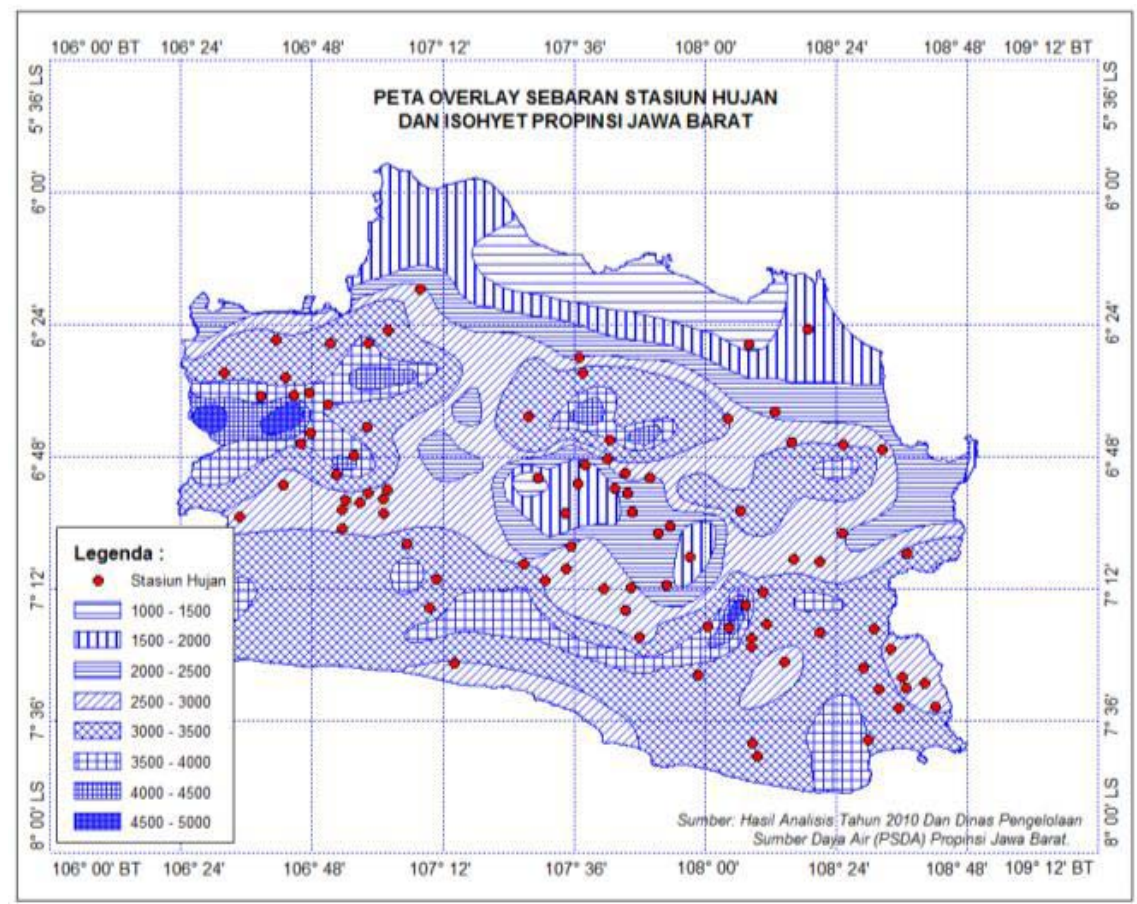

Gambar 9. Peta Hasil Overlay Sebaran Stasiun Hujan dan Isohyet Propinsi Jawa Barat

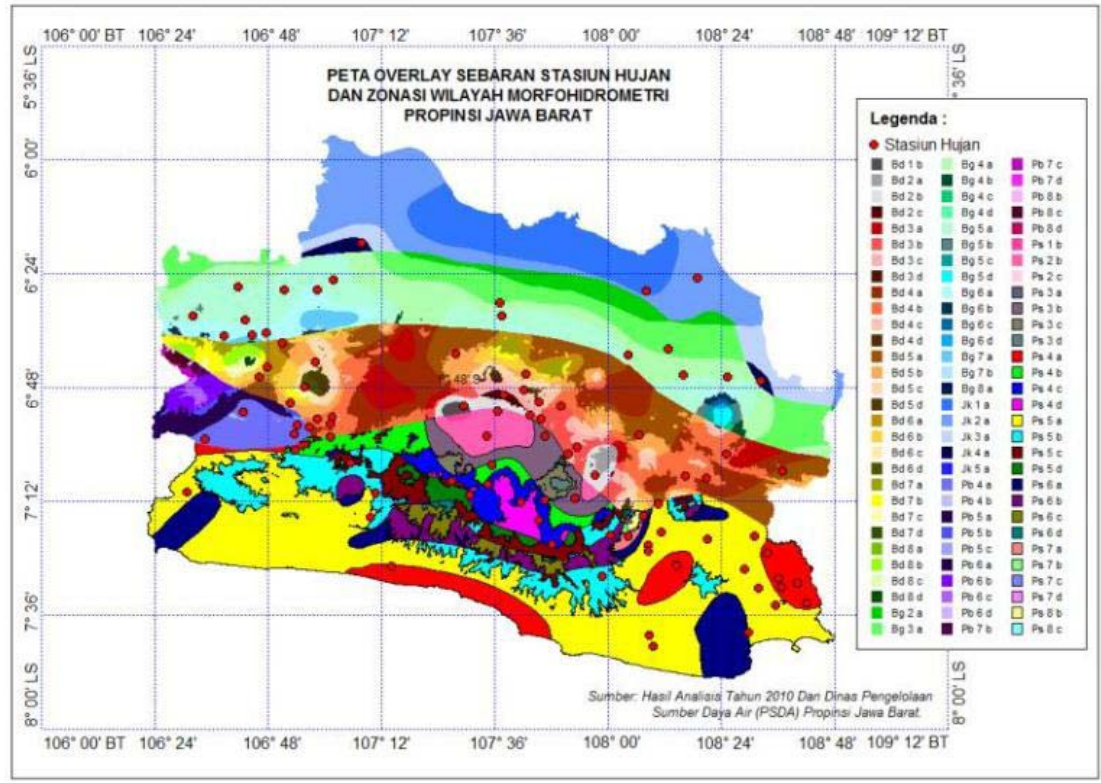

Gambar 10. Peta Hasil Overlay Sebaran Stasiun Hujan dan Fisiomorfohidro Propinsi Jawa Barat 


\section{SIMPULAN}

Jawa Barat terbagi ke dalam beberapa wilayah fisiomorfohidro yang terbagi ke dalam 90 zona. Setiap zona memiliki karakteristik yang khas ditinjau dari aspek fisiografi, topografi, dan sebaran curah hujan/isohyet. Hasil overlay peta sebaran stasiun hujan dengan peta fisiografi menunjukkan bahwa stasiun hujan di Jawa Barat tersebar di semua zona tetapi tidak merata. Ketidak merataan juga terlihat dari hasil overlay sebaran stasiun hujan dengan topografi, dan isohyet. Berdasarkan hasil overlay peta zonasi wilayah fisiomorfohidro dan peta persebaran stasiun hujan di Jawa Barat, maka diketahui bahwa masih banyak zonasi-zonasi wilayah yang belum memiliki stasiun hujan pewakil.

\section{DAFTAR PUSTAKA}

Chow, V.T., Maidment, D.R., and Mays L.W. (1988). Applied hydrology. New York: McGraw-Hill Book Company, St. Louis, etc.; 110-113.

Rohmat, Dede. (2002). Formulasi pola intensitas hujan berdasarkan kejadian hujan durasi pendek (contoh kasus untuk DAS Cimanuk Hulu). Bandung: Yayasan Geofera.

Soekarno, I., Rohmat, Dede. (2010). Persamaan Pola Intensitas Hujan Fungsi dari Durasi dan Probabilitas Hujan untuk Kawasan Daerah Aliran Sungai (DAS) Bagian Hulu. Jurnal Media Komunikasi BMPTTSSI, Vol. No.2006.

Soekarno, Indratmo, dan Dede Rohmat. (2006). Kajian Koefisien Limpasan Hujan Cekungan Kecil Berdasarkan Model Infiltrasi Empirik untuk DAS Bagian Hulu (Kasus Cekungan Kecil Cikumutuk DAS Cimanuk Hulu). Jurnal Teknik Sipil-ITB, Vol. 13 No. 1, Januari 2006. Bandung: ITB.

Soekarno, Indratmo, dan Dede Rohmat. (2005). Pola Intensitas Hujan Menurut Durasi Hujan dan Probabilitas Hujan pada DAS Cimanuk Bagian Tengah. Seminar "Banjir dan Kekeringan", 7 Sept. 2005. Jakarta: Masyarakat Hidrologi Indonesia. 